\title{
Juvenile onset spondyloarthropathies: therapeutic aspects
}

\section{R Burgos-Vargas}

Ann Rheum Dis 2002;61 (Suppl III):iii33-iii39

See end of article for author's affiliation

....................

Correspondence to: Dr R Burgos-Vargas, Hospital General de México, Dr Balmis 148 México DF 06726; burgosv@attglobal.net

\begin{abstract}
Juvenile onset spondyloarthropathy $(\mathrm{SpA})$ is a term that refers to a group of human leucocyte antigen (HLA)-B27 associated inflammatory disorders affecting children under the age of 16 years, producing a continuum of clinical symptoms through adulthood. This disease is characterised by enthesopathy and arthropathy affecting the joints of the lower extremities and seronegativity for IgM rheumatoid factor and antinuclear antibodies. Children usually present with undifferentiated SpA and progress to differentiated forms over time. Except for the prevalence of some clinical features at onset, the pathogenic and clinical aspects of juvenile onset SpAs resemble those of the adult disease. Thus application of the same or similar therapeutic measures for both juvenile and adult onset SpAs seems logical. Current treatments for juvenile onset SpA provide symptomatic improvement, but do not alter disease progression. The increased expression of tumour necrosis factor alpha (TNF $\alpha$ ) in synovial tissue of patients with adult and juvenile onset SpA and its correlation with infiltration of inflammatory mediators into the synovia suggest a significant pathogenic role of this cytokine. Clinical trials of anti-TNF $\alpha$ antibody (infliximab) therapy in patients with adult onset SpA have demonstrated significant clinical improvement in inflammatory pain, function, disease activity, and quality of life in correlation with histological and immunohistochemical evidence of modulation of synovial inflammatory processes. These promising findings suggest that anti-TNF $\alpha$ therapy may confer similar benefits in patients with juvenile onset $\mathrm{SpA}$.
\end{abstract}

Uvenile onset spondyloarthropathies (SpAs) may be defined as a heterogeneous group of human leucocyte antigen (HLA)-B27 associated inflammatory syndromes that affect children and adolescents under the age of 16 years and produce a continuum of clinical symptoms through adulthood. This disease group includes the seronegative enthesopathy and arthropathy (SEA) syndrome; juvenile onset ankylosing spondylitis (AS); ankylosing tarsitis; reactive arthritis (ReA); arthropathies associated with inflammatory bowel disease (IBD) - for example, Crohn's disease or ulcerative colitis; and HLA-B27 associated juvenile onset psoriatic arthritis. ${ }^{1}$

The hallmarks of this disease group are enthesopathy and arthropathy (and also tenosynovitis) affecting the peripheral joints, particularly those of the lower extremities. ${ }^{2}$ A significant proportion of patients will develop arthritis of the sacroiliac and spinal joints and a variety of extra-articular manifestations involving the gut, eyes, skin, and mucosa. Characteristically, IgM rheumatoid factor (IgM RF) and antinuclear antibodies (ANA) are absent in serum.

Except for some features at onset, specifically an increased prevalence of peripheral disease and the rare occurrence of axial symptoms, juvenile onset SpAs resemble adult forms of SpA in their association with HLA-B27 and bacteria, clinical expression, and radiological features. ${ }^{2}$ It would appear that both juvenile and adult forms of SpA share common pathogenetic mechanisms, thus providing a rationale for the same or similar therapeutic measures.

The benefits of current treatment options in juvenile onset SpA are limited to symptomatic improvement. They do not target pathogenetic mechanisms and thus cannot prevent disease progression, subsequently failing to alter the long term consequences of juvenile onset SpA. However, promising outcomes of recent investigations of new immunomodulating treatments in adult forms of SpAs, ${ }^{3-8}$ in particular the anti-tumour necrosis factor $\alpha(\mathrm{TNF} \alpha)$ agents, suggest the possibility of potential new therapeutic approaches for patients with juvenile onset SpA. The inhibition of inflammatory processes by such agents in early disease may potentially prevent subsequent cartilage damage and structural changes. ${ }^{7}$
Several extensive reviews of juvenile onset SpAs are available. ${ }^{2-11}$ This paper provides a brief overview of juvenile onset SpA and the treatment of the disease, with a view to potential new treatment approaches.

\section{EPIDEMIOLOGY}

Epidemiological data from open populations ${ }^{12-15}$ and clinical populations ${ }^{16-20}$ suggest that the prevalence, incidence, and relative frequency of juvenile onset SpA are increasing. Juvenile onset SpAs account for a significant proportion of children with juvenile arthritides. Data from paediatric rheumatology clinics in Canada, the United Kingdom, and the United States indicate that juvenile onset SpAs account for a significant proportion of children presenting with juvenile arthritis. ${ }^{16-19}$ The Canadian study estimated the annual incidence for juvenile onset SpA (excluding psoriatic arthritis) at 1.44 per 100000 children at risk (95\% confidence interval (CI) 1.12 to 1.87$)$, compared with an estimated annual incidence for all forms of chronic arthritis of 4.08 (95\% CI 3.62 to 4.60$){ }^{16}$

Paediatric rheumatology clinics noted an increase in the prevalence of juvenile onset SpA from $0 \%$ to $16 \%$ in the 1970 s to $31 \%$ in the 1980 s. $^{1}$ This may also reflect an increase in recognition of SpA in children, distinct from other rheumatic conditions including juvenile rheumatoid arthritis (JRA), following published descriptions in 1982 of SEA syndrome ${ }^{21}$ and HLA-B27 associated spondyloarthritis and enthesopathy in children. ${ }^{22}$ None the less, today, the actual incidence of juvenile

Abbreviations: ANA, antinuclear antibodies; $A S$, ankylosing spondylitis; BASDAI, Bath AS Disease Activity Index; BASFI, Bath AS Functional Index; CRP, $C$ reactive protein; ESR, erythrocyte sedimentation rate; IBD, inflammatory bowel disease; IL, interleukin; JCA, juvenile chronic arthritis; JRA, juvenile rheumatoid arthritis; NSAID, non-steroidal anti-inflammatory drug; ReA, reactive arthritis; RF, rheumatoid factor; SEA, seronegative enthesopathy and arthritis; SpA, spondyloarthropathy; $\mathrm{TNF} \alpha$, tumour necrosis factor $\alpha$; VAS, visual analogue scale 
onset SpAs may be higher than reported because of several undefined factors: nomenclature, criteria for diagnosis, and classification; and lack of a clear boundary between the different arthropathies of childhood. Furthermore, in the case of juvenile onset AS, in which peripheral arthritis precedes symptomatic axial arthritis by 5-10 years, the absence of apparent inflammatory or structural changes manifesting as clinical or radiographic features may lead to misdiagnosis of the disease as JRA. ${ }^{93}$ Thus, a large proportion of patients with juvenile onset SpA may be misdiagnosed as having JRA or juvenile chronic arthritis (JCA).

\section{RELATIONSHIP WITH OTHER FORMS OF JUVENILE ARTHRITIS}

Children with early onset SpA have been classified within the oligoarticular/pauciarticular onset subgroups of JRA/JCA. Differential diagnosis between juvenile onset SpA and JRA/JCA includes a positive history of SpA in a first or second degree relative, high frequency of HLA-B27, male predominance (except in juvenile onset psoriatic arthritis), frequent enthesitis, peripheral arthritis asymmetrically affecting the lower extremities, and absence of ANA and IgM RF. ${ }^{9}$ Enthesopathy and tarsal disease in children presenting with arthritis confined to the lower extremities differentiate juvenile onset AS from JRA within one year of symptoms. ${ }^{24}$ Today, juvenile onset SpA is recognised as a different subset within the various forms of juvenile arthritis; recently, the term "enthesitis related arthritis" and pertinent diagnostic criteria were proposed by the International League Against Rheumatism (ILAR) Task Force Group to identify this subset of paediatric patients. ${ }^{25}$

\section{DISEASE PROFILE \\ Pathogenesis}

The role of HLA-B27 and bacteria in disease pathogenesis appears similar to that of adult onset forms. Age related factors-for example, maturity of the immune and endocrine systems and bacterial exposure, appear to have an additional role in children. ${ }^{26-29}$

\section{HLA-B27 and other genetic markers}

Sixty to 90 per cent of patients with juvenile onset SpA have the HLA-B27 antigen. ${ }^{2}$ At least 20 subtypes of HLA-B27 (named consecutively from $\mathrm{B} 27^{*} 01$ ) have been identified, of which HLA-B $27^{*} 05$ is the subtype most commonly found in juvenile onset SpA. ${ }^{230}{ }^{31}$ Other non-HLA-B27 antigens may also contribute to AS in different patient populations. ${ }^{232}$

HLA-B27 antigen may contribute to the pathogenesis of SpA through several proposed mechanisms: (a) presentation of bacterial antigens to CD8 lymphocytes ${ }^{33} ;(b)$ mimicry of bacterial antigen molecules ${ }^{34} ;(c)$ acquisition of antigenic properties after modification during bacterial infections ${ }^{35} ;(d)$ modulation of presentation, processing, or elimination of Gram negative pathogens ${ }^{3637}$; and (e) interference with antigen presentation to T lymphocytes. ${ }^{38}$ In addition, HLA-B27 derived peptides may be presented by major histocompatibility complex class II molecules to CD4 lymphocytes. ${ }^{33}$ These mechanisms suggest an interaction between HLA-B27 and the $\mathrm{T}$ cell response, possibly triggered by a bacterial antigen, as in the case of ReA. ${ }^{33}$

\section{Bacterial infections and arthritogenic bacteria}

In adults, enteric and non-gonococcal urogenital bacterial infections are considered important triggers in the SpAs, specifically ReA. ${ }^{2}$ ReA has been associated, by the detection in synovial tissues of bacteria-specific antibodies or bacterial antigens, with Salmonella, ${ }^{39}{ }^{40}$ Shigella, ${ }^{41}$ Yersinia, ${ }^{42}$ and Chlamydia infections. ${ }^{43}{ }^{44}$ Klebsiella has also been implicated in the aetiology of AS. ${ }^{45}$ These findings, together with reports of molecular mimicry between some Klebsiella, Salmonella, Yersinia, and Shigella amino acid sequences and HLA-B27, 34478 represent the primary evidence for the role of bacterial infections in the pathogenesis of SpA. In addition, increased T lymphocyte response specific for the triggering of bacterial antigen has been demonstrated in synovial fluid taken from patients with ReA.950 However, very few studies have examined the interaction between bacteria, HLA-B27, and other genes in children with SpA. The micro-organisms implicated more frequently in children with ReA include Salmonella spp, and Yersinia enterocolitica, but rarely Shigella flexneri, Chlamydia pneumoniae, and Chlamydia trachomatis. ${ }^{2651}$

\section{Gut}

In both children and adults, gut inflammation (in association with Crohn's disease or ulcerative colitis) is closely linked to SpA, particularly AS and ReA..$^{52-57}$ Ileocolonoscopy studies have shown that non-specific inflammatory lesions of the terminal ileum or colon mucosa occur in $75-80 \%$ of patients with $\mathrm{JCA}^{5355}$ and are associated with a high risk of progression to AS. ${ }^{535}$ These findings correspond with ileocolonoscopic and clinical findings in adults with these forms of SpA..$^{56} 57$ Nonspecific IBD rarely causes a definitive clinical picture, but repeated histopathological and radionuclide studies of the gut may disclose acute and chronic inflammatory changes in the mucosa and submucosa of the terminal ileon and colon resembling Crohn's disease and ulcerative colitis in more than two thirds of patients. ${ }^{55859}$

\section{Immune response}

The influence of peripheral blood and synovial fluid cells, cytokines, and cell and inflammatory mediators on the pathogenesis of SpA is the subject of continuing investigation. Cellular infiltrates in synovial tissue from peripheral and sacroiliac joints of adults with SpA show a predominance of $\mathrm{CD} 4+$ over CD8 + T lymphocytes and a significant percentage of $\mathrm{CD} 14+$ macrophages. ${ }^{64}$ TNF $\alpha$, TNF $\beta$, interferon $\gamma$, interleukin (IL)4, IL6, IL2, and transforming growth factor $\beta$ are also present in synovial tissue from adults and children with SpA. ${ }^{49} 50$ 60-64

In synovial tissue specimens from patients with juvenile onset SpA, expression of TNF $\alpha$ is prominent, ${ }^{63}$ consistent with high levels of TNF $\alpha$ mRNA seen in synovial tissues from adults with active $\mathrm{AS}^{60}$ Increased production of TNF $\alpha$ correlates closely with increased infiltration of inflammatory cells (T cells and macrophages) into the synovia. ${ }^{63} \mathrm{TNF} \beta$ is also present in the synovia of patients with juvenile onset SpA, but to a smaller extent than TNF $\alpha .{ }^{63}$ Increased production of these cytokines is associated with increased expression of the TNF receptor, p55, and to a smaller extent, p75. ${ }^{63}$ High levels of activation of CD8 cells also occur. ${ }^{61}$ Taken together, these findings suggest that TNF, particularly TNF $\alpha$, may have a central role in mediating enhanced local inflammatory responses in juvenile onset SpA.

\section{CLINICAL MANIFESTATIONS}

The spectrum of disease manifestations is wide (table 1$){ }^{2}$ Enthesopathy and arthropathy at peripheral sites are trademarks of juvenile onset SpA. Throughout time, the disease progresses from undifferentiated forms to differentiated SpA. Undifferentiated inflammatory conditions are characterised by peripheral enthesitis and arthritis, primarily affecting the lower limb entheses and joints, particularly the feet. This subgroup includes isolated episodes of arthritis, enthesitis, tendonitis, dactylitis, and SEA syndrome. ${ }^{12}$ SEA syndrome is associated with a high probability of evolution to a definite $\mathrm{SpA}$, although it may also be an isolated form of juvenile onset SpA. ${ }^{2}$ In one study, $69 \%$ of children presenting with SEA syndrome developed definite or probable SpA within 11 years after symptom onset. ${ }^{65}$ Differentiated SpA includes conditions 
Table 1 Clinical spectrum of juvenile onset spondyloarthropathies ${ }^{2}$

\begin{tabular}{|c|c|}
\hline SpA & Clinical features \\
\hline Isolated arthritis & $\begin{array}{l}\text { - Usually mono- or oligoarthritis affecting } \leqslant 5 \text { joints of the lower extremities } \\
\text { - Most frequently affects the knee }\end{array}$ \\
\hline Isolated enthesitis & $\begin{array}{l}\text { - Occurs in single or multiple sites of the lower extremities, often at the feet (plantar fascia insertion, and less } \\
\text { frequently, the Achilles insertion to the calcaneus) }\end{array}$ \\
\hline SEA syndrome & $\begin{array}{l}\text { - Enthesopathy and arthropathy } \\
\text { - Seronegative for rheumatoid factor and antinuclear antibodies } \\
\text { - Predominantly affects the feet } \\
\text { - Progresses from mono- or oligoarthritis to polyarthritis } \\
\text { - HLA-B27 positive children frequently, HLA-B27 negative children rarely, evolves into AS }\end{array}$ \\
\hline Juvenile onset AS (see text) & $\begin{array}{l}\text { - Usually preceded by isolated symptoms or SEA syndrome } \\
\text { - Lower extremity oligoarthritis in first } 6 \text { months, progressing to polyarthritis by } 12 \text { months after onset } \\
\text { - High frequency of arthritis in lower extremity joints after } 10 \text { years (fig } 2 \text { ) } \\
\text { - Radiographic osteopenia, joint space narrowing, or ankylosis of the tarsal, hip, and axial joints } \\
\text { - Increased spinal or sacroiliac pain and stiffness and limited anterior spinal flexion or chest expansion apparent at } \\
2.5 \text { years, maximal at } 5-10 \text { years (fig } 1 \text { ) } \\
\text { - Early onset of axial symptoms in } \leqslant 15 \% \text { of patients } \\
\text { - Constitutional symptoms in } 5-10 \% \text { of patients with active disease* } \\
\text { - Non-granulomatous acute uveitis in } \leqslant 27 \% \text { of patients } \\
\text { - High incidence of non-specific IBD ( } \leqslant 80 \%)\end{array}$ \\
\hline Juvenile onset psoriatic arthritis & $\begin{array}{l}\text { - Various clinical forms, one of them of the SpA type } \\
\text { - Initial oligoarthritis (most frequently in the knees, ankles, feet, and hands) progresses to upper and lower extremity } \\
\text { - Radiogritis } \\
\text { - Sacroiliitis and axial symptoms occur in some cases } \\
\text { - Enthesitis affects the lower limb } \\
\text { - HLA-B27 associated } \\
\text { - Should be differentiated from most other forms of juvenile psoriatic arthritis, which are unrelated to SpA and are most } \\
\text { frequently found }\end{array}$ \\
\hline IBD associated $\mathrm{SpA}$ & $\begin{array}{l}\text { - Typically involves episodes of lower extremity peripheral arthritis coinciding with gastrointestinal symptoms of IBD } \\
\text { (CD, UC, or non-specific IBD) } \\
\text { - Axial involvement is relatively uncommon } \\
\text { - Non-specific IBD changes occur in } \leqslant 80 \% \text { of cases of juvenile onset } \mathrm{SpA} \\
\text { - May progress to AS }\end{array}$ \\
\hline $\operatorname{ReA}$ & $\begin{array}{l}\text { - Onset approximately } 4 \text { weeks after gastrointestinal or genitourinary bacterial infection (also see text) } \\
\text { - Lower extremity oligoarthritis and enthesitis typically occur } \\
\text { - Prevalent HLA-B27 }\end{array}$ \\
\hline \multicolumn{2}{|c|}{$\begin{array}{l}\text { *Constitutional symptoms include high grade fever, weight loss, muscle weakness and atrophy, fatigue, lymph node enlargement, leucocytosis, and } \\
\text { anaemia. } \\
\text { AS, ankylosing spondylitis; CD, Crohn's disease; IBD, inflammatory bowel disease; MTP, metatarsophalangeal; ReA, reactive arthritis; SEA, seronegative } \\
\text { enthesopathy and arthropathy; SpA, spondyloarthropathy; UC, ulcerative colitis. }\end{array}$} \\
\hline
\end{tabular}

with evidence of structural changes - that is, radiographic sacroiliitis, spinal disease, or tarsal ankylosis, extra-articular symptoms (for example, psoriasis or IBD), or laboratory features (for example, serological or bacteriological culture) diagnostic of ReA; IBD related arthropathy, ankylosing tarsitis, AS, and psoriatic spondyloarthritis.

Most patients presenting with both arthritis and enthesitis become symptomatic within the first year of diagnosis. The spine and sacroiliac joint may be affected early in the course of the disease. Arthropathy consists of tenderness, swelling, and limited joint movement, most often in the knee, mid-tarsus, and ankle, following a monoarticular or asymmetrically pauciarticular pattern. Arthritis in patients with juvenile onset SpA follows a variable course, occurring as single episodes of mono- or oligoarthritis, intermittent episodes of arthritis in the joints alternating with partial or complete remission, or severe persistent disease affecting multiple joints, IBD, juvenile onset AS, or ankylosing tarsitis. Enthesitis presents with pain and tenderness upon application of pressure, soft tissue swelling secondary to inflammation of tendon sheaths, and adjacent bursae. Enthesitis often occurs at the feet and is often severe enough to be disabling. Enthesitis follows a variable course, occurring as short term episodes of active inflammation, intermittent episodes of enthesis alternating with partial or complete remission, or severe and persistent enthesitis at multiple sites. Persistent enthesitis is associated with cortical bone erosions and joint ankylosis.

Disease activity and damage may be assessed by different methods. Joints and entheses with active inflammation as well as peripheral joint and spinal mobility are useful measures in juvenile onset SpA. Possibly, the application of a number of disease activity indices developed for adult onset populations (for example, visual analogue scale (VAS) for pain and Bath AS Disease Activity Index (BASDAI)) and for other forms of childhood arthritis (Childhood Health Assessment Questionnaire or CHAQ), may be useful. Imaging and laboratory assessment methods may include radiography, ultrasonography, and magnetic resonance, $\mathrm{C}$ reactive protein (CRP), and erythrocyte sedimentation rate (ESR). Structural damage may be evaluated by determining the functional status and monitoring radiographic changes of the feet, hips, sacroiliac joints, and spine. Functional ability also plays a significant part in the evaluation of juvenile onset SpA. ${ }^{66}$ As with disease activity indices, adult onset instruments such as the Bath AS Functional Index (BASFI), as well as instruments for children with other forms of arthritis, may be useful in juvenile onset SpA.

\section{Course of the disease}

Children with juvenile onset SpA may enter into full remission after one or two mild or moderate episodes of disease activity, 


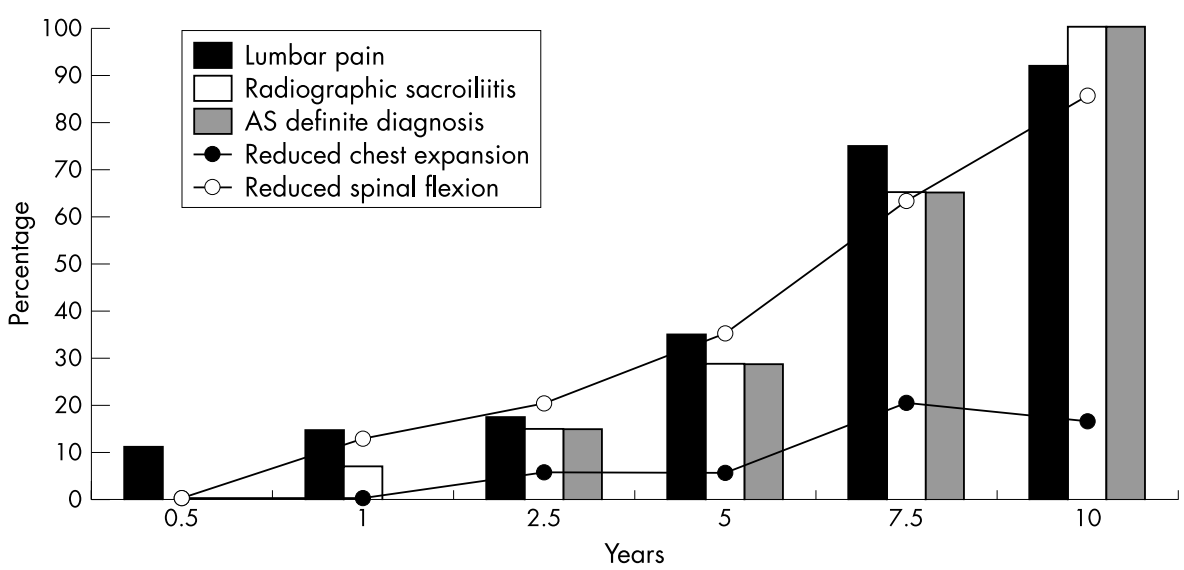

Figure 1 Progression of children with juvenile onset undifferentiated spondyloarthropathy to fulfilment of the modified New York diagnostic criteria for AS over a 10 year period. The percentages of patients fulfilling each criterion are shown for each time. Most patients fulfil diagnostic criteria for definite AS after a mean of 7.5 years (range 5-10) after the onset of symptoms of juvenile onset SpA. Reproduced with permission of the authors and Rheumatic Disease Clinics of North America from Burgos-Vargas R et al. Rheum Dis Clin North Am 1997;23:569-98. Copyright () 1997 W B Saunders Company.

or they may have recurrent episodes of enthesitis and arthritis extending to the spine and sacroiliac joints (figs 1 and 2). Others may have persistent inflammation, with severe consequences early on in the course of the disease. Changes in disease activity occur at various intervals. Chronic course is characterised by an increasing number of entheses and joints affected. ${ }^{24}$ The functional ability of children, adolescents, and adults with juvenile onset SpA may be severely affected by disease activity and disease damage. Patients with active disease present with diverse levels of joint-limited range of movement and interference of daily life activities. Patients with severe signs and symptoms may have significantly impaired function, which may subside during recovery.

Long term follow up of HLA-B27 children with JCA/JRA has shown that $66-75 \%$ develop sufficient clinical and radiographic signs of spondylitis and sacroiliitis to fulfil the diagnostic criteria for AS. ${ }^{67}{ }^{68}$ Similarly, $70-90 \%$ of children with SEA syndrome fulfil the same criteria 5-10 years after onset. ${ }^{23}{ }^{69}$ Children with Reiter's syndrome or ReA may follow a similar course, ${ }^{70}$ but most of them are likely to go into full remission after one episode of disease activity. ${ }^{71-73}$

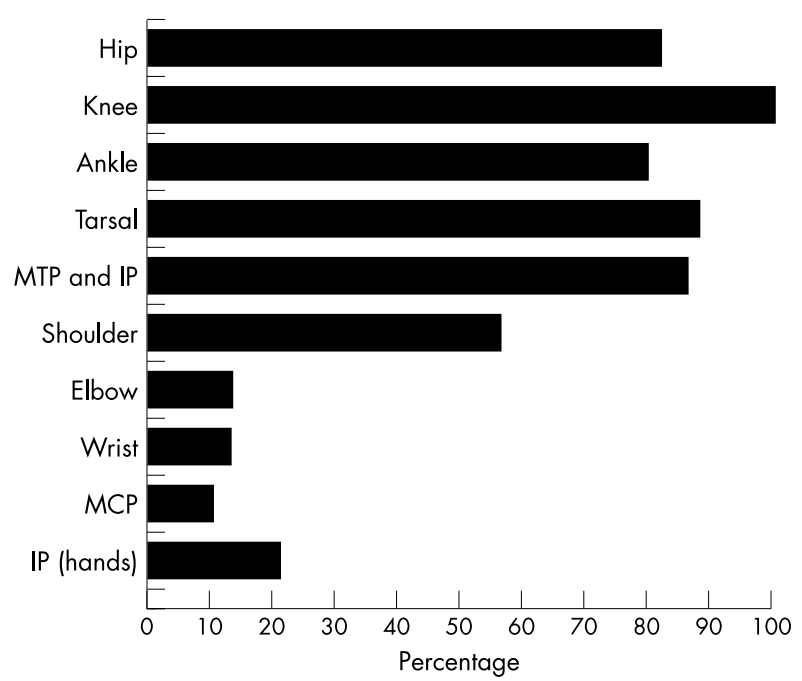

Figure 2 Cumulative frequency of joint disease in juvenile onset ankylosing spondylitis 10 years after diagnosis. Reproduced with permission of the authors and Rheumatic Disease Clinics of North America from Burgos-Vargas R et al. Rheum Dis Clin North Am 1997;23:569-98. Copyright (C) 1997 W B Saunders Company.
Flato et al found that disease activity for more than five years predicted disability in juvenile onset $\mathrm{SpA} .{ }^{74}$ According to Minden et al, the probability of remission is only $17 \%$ after five years of disease. ${ }^{75}$ Nearly $60 \%$ of children with SpA have moderate to severe limitations after 10 years of disease. ${ }^{75}$ In comparison with adults, patients with juvenile onset AS require more hip replacements throughout the course of disease, and more patients are in functional classes III and IV. $^{76-78}$ Shortly after onset, foot enthesitis and arthritis and, less commonly, ankle and knee arthritis, produce pain and severe limitations from walking or standing up. As a result, children with SpA may abandon school and stop participating in sports and social activities. Sometime later, joint stiffness, muscle atrophy, and flexure contractures contribute to functional limitations.

Structural changes of the feet and hips lead to permanent functional limitations to which spinal disease may contribute. Patients with persistent tarsitis and enthesitis develop severe structural problems, including various degrees of tarsal fusion or ankylosing tarsitis and enthesophytosis (fig 3). Some patients develop severe problems of the spine, specifically discitis and various deformities, which dramatically reduce their physical activity. Functional status of patients with juvenile onset SpA may reach class IV.

\section{CURRENT TREATMENT}

Treatment of juvenile onset SpA can be frustrating. Although therapeutic measures are aimed at alleviating symptoms of inflammation (that is, pain), maintaining or improving range of motion and muscle strength, preventing deformity, preserving function, and preventing or managing disease complications, short and long term results may be very unsatisfactory. Early and continuous physical and occupational therapy are critical to the patient's maintenance of independent functioning. Physical measures include resting splints for inflamed joints and orthoses to protect entheses, local application of heat or cold packs for pain relief, and exercises to improve range of motion of the spine and chest.

Non-steroidal anti-inflammatory drugs (NSAIDs) are the initial preferred pharmacological treatment for juvenile onset $\mathrm{SpA}^{2}$ Sulfasalazine may be useful in juvenile onset SpA, but differences from placebo may be only slightly significant. ${ }^{79}$ Short term oral corticosteroid treatment at low to moderate doses may be required to control severe episodes of arthritis; higher doses may be needed for severe enthesitis. Intraarticular corticosteroid injection (triamcinolone hexacetonide, $1 \mathrm{mg} / \mathrm{kg}$ per joint) may resolve persistent arthritis, 

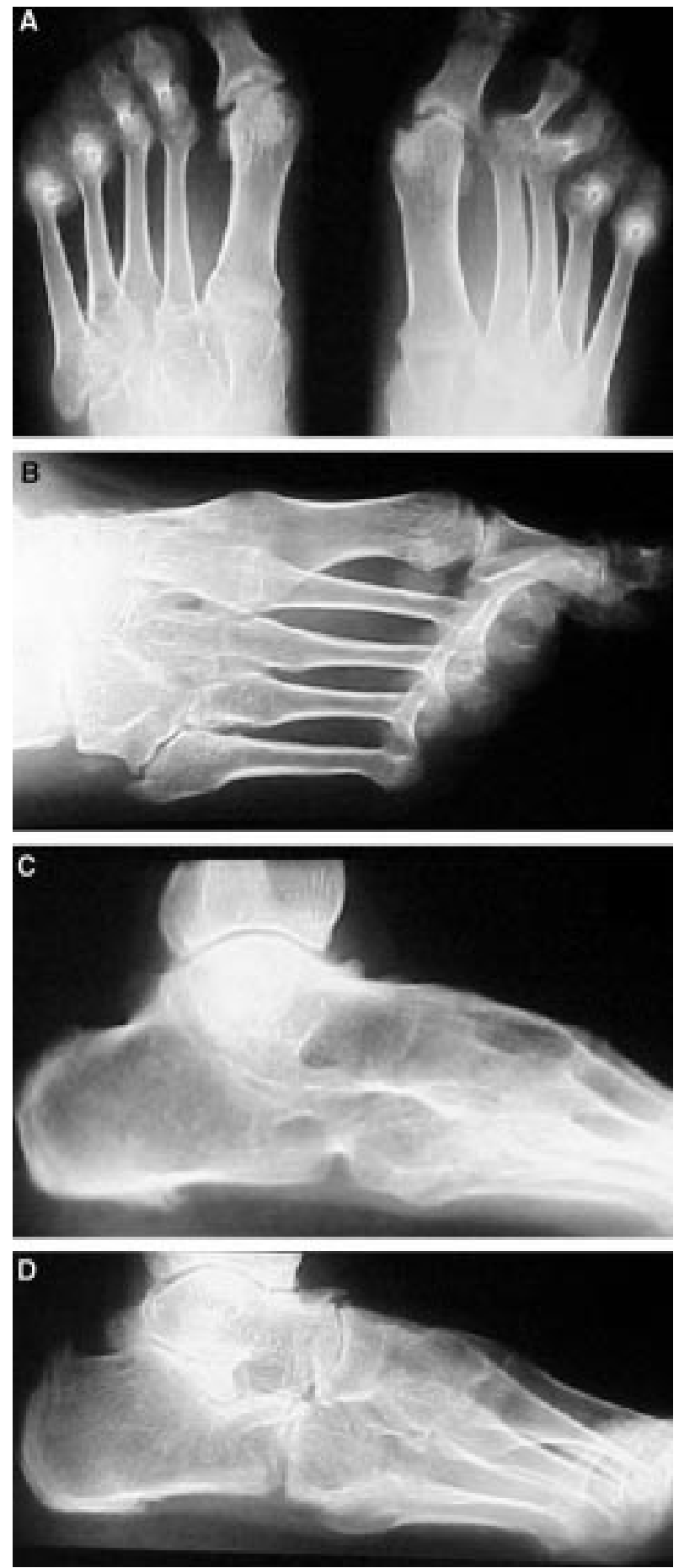

Figure 3 Long term structural changes of the feet in a 20 year old patient with juvenile onset AS. (A) Dorsoplantar aspect showing metatarsophalangeal joint surface erosions and misalignment. (B) Left foot oblique view showing ankylosis of the first metatarsal and cuneal bones, metatarsophalangeal joint subluxations and enthesophytes at the margin of the 5 th metatarsal-cuneal joint. (C, D) Right and left lateral views showing a spectrum of changes, including enthesophytosis at the plantar fascia attachment to the calcaneus and complete fusion of the tarsal bones (ankylosing tarsitis in $\mathrm{C}$ and enthesophytosis of the talonavicular joint in D). These previously unpublished figures are provided courtesy of Dr R Burgos-Vargas.

refractory to NSAIDs, for 6-24 months. ${ }^{9}$ Methotrexate and other disease modifying antirheumatic drugs do not seem to have a significant role in juvenile onset SpA.

Thus, the current treatment options for juvenile onset SpA are limited. Furthermore, there is no evidence that any avail- able therapeutic intervention prevents the progression of disease. Recently, attention has been given to the inflammatory processes underlying rheumatic conditions as potential sites for therapeutic intervention. For SpA, high levels of the proinflammatory cytokine TNF $\alpha$ have been documented in synovial tissue from patients with juvenile onset $\mathrm{SpA},{ }^{63}$ and adults with active AS ${ }^{60}$ TNF $\alpha$ is a cytokine produced mainly by monocytes and macrophages that mediates several inflammatory and immunoregulatory activities along the inflammatory cascade. $^{80}$ Its activities include up regulation of several endothelial adhesion receptors, activation of lymphocytes and neutrophils, induction of synthesis of proinflammatory cytokines and chemokines, stimulation of other inflammatory mediators, induction of synthesis of metalloproteinases that mediate bone and cartilage destruction, and mediation of pain. ${ }^{80}$ In addition, TNF $\alpha$ has a key role in the pathogenesis of $\mathrm{IBD}^{81}{ }^{82}$ and its neutralisation by anti-TNF $\alpha$ has proved effective in Crohn's disease ${ }^{83}$ and IBD strongly associated with AS.

\section{ANTI-TNF $\alpha$ THERAPY IN JUVENILE ONSET SPA}

The anti-TNF $\alpha$ agents etanercept and infliximab have both been used in juvenile onset SpA. The effect of such agents in juvenile onset SpA can be rather striking from the clinical point of view. Using etanercept, a TNF $\alpha 75 \mathrm{kDa}$ receptor IgGl fusion protein, Reiff and Henrickson found a prolonged reduction in the number of active joints, morning stiffness, and ESR in eight patients with juvenile onset AS treated with $0.2-0.8 \mathrm{mg} / \mathrm{kg}$ subcutaneously twice weekly. ${ }^{84}$ The mean age of the group was 15.9 years (range 12-25), and the mean follow up of these patients was 15.4 months. All patients tolerated etanercept without side effects.

It should be noted, however, that this author (BurgosVargas, unpublished observations) has treated six patients with juvenile onset $\mathrm{SpA}$ with $5 \mathrm{mg} / \mathrm{kg}$ of infliximab (a chimeric human-murine monoclonal anti-TNF $\alpha$ antibody) at weeks $0,2,6$, and then every two months for nearly a year. A remarkable reduction was found in peripheral and axial signs of disease after the first and second infusion of the drug. Improvement includes a significant decrease in the number of peripheral joints with active arthritis and tender entheses, in CRP values, in pain as evaluated by a VAS, as well as in BASDAI and BASFI scores. Interestingly, however, concurrent uveitis in one patient with juvenile onset AS seemed unresponsive to infliximab.

Although the use of anti-TNF $\alpha$ agents is still limited in children and adolescents with juvenile onset SpA, it seems that the effect of infliximab and etanercept in these disorders is at least as good as that seen in adult onset patients. The response appears so significant that most patients may stop NSAIDs and other drugs. Indeed, long term follow up is required to determine whether anti-TNF $\alpha$ agents can stop the devastating events that characterise juvenile onset SpA.

\section{CONCLUSIONS}

Juvenile onset SpA is a disorder distinct from JRA. The pathogenesis, radiological and clinical manifestations, and histopathology of the pathogenic lesions of juvenile onset SpA resemble those of the adult onset disease. Thus, treatment responses similar to those elicited in patients with adult onset SpA are expected in patients with the juvenile onset disease, and similar treatment strategies are employed in juvenile and adult onset SpA. Current treatments provide symptomatic relief but do not alter the natural course of the disease. New treatments are under investigation that target immune responses and cellular inflammatory processes which play a part in the pathogenesis of SpA. TNF $\alpha$ has been identified as a predominant proinflammatory cytokine in synovial tissue of patients with SpA. Clinical, histological, and immunohistochemical findings of studies of anti-TNF $\alpha$ antibody therapy in adult onset SpA suggest the possibility of altering the 
progression of disease coincident with clinical improvement. These findings in adult onset SpA suggest that anti-TNF $\alpha$ therapy may confer similar benefits in juvenile onset SpA.

\section{Author's affiliation}

R Burgos-Vargos, Research Division, Hospital General de México,

Faculty of Medicine, Universidad Nacional Autónoma de México, México City, México

\section{REFERENCES}

1 Burgos-Vargas R. Spondyloarthropathies and psoriatic arthritis in children. Curr Opin Rheumatol 1993;5:634-43.

2 Burgos-Vargas R, Pacheco-Tena C, Vazquez-Mellado J. Juvenile-onset spondyloarthropathies. Pediatr Rheumatol 1997;23:569-98.

3 Baeten D, Kruithof E, Van Den Bosch F, Demetter P, Van Damme N Cuvelier $C$, et al. Immunomodulatory effects of anti-tumor necrosis factor $\alpha$ therapy on synovium in spondylarthropathy. Histologic findings in eight patients from an open-label pilot study. Arthritis Rheum 2001;44:186-95.

4 Kruithof E, Van Den Bosch F, Baeten D, Herssens A, De Keyser F Mielants $\mathrm{H}$, et al. Repeated infusions of infliximab, a chimeric anti-TNF $\alpha$ monoclonal antibody, in patients with active spondyloarthropathy: one year follow up. Ann Rheum Dis 2002;61:207-12

5 Van Den Bosch F, Kruithof E, Baeten D, De Keyser F, Mielants H, Veys EM. Effects of a loading dose regimen of three infusions of chimeric monoclonal antibody to tumour necrosis factor $\alpha$ (infliximab) in spondyloarthropathy: an open pilot study. Ann Rheum Dis 2000;59:428-33.

6 Van Den Bosch F, Kruithof E, Baeten D, Herssens A, de Keyser F, Mielants $\mathrm{H}$, et al. Randomized double-blind comparison of chimeric monoclonal antibody to tumor necrosis factor $\alpha$ (infliximab) versus placebo in active spondyloarthropathy. Arthritis Rheum 2002:46:755-6.

7 Braun J, Xiang J, Brandt J, Maetzel H, Haibel H, Wu P, et al. Treatment of spondyloarthropathies with antibodies against tumour necrosis factor $\alpha$ : first clinical and laboratory experiences. Ann Rheum Dis. 2000;59(suppl I):i85-9

8 Braun J, Brandt J, Listing J, Zink A, Alten R, Krause A, et al. Treatment of active ankylosing spondylitis with infliximab - a randomized controlled multicenter trial. Lancet 2002;359:1 187-93.

9 Cabral DA, Malleson PN, Petty RE. Spondyloarthropathies of childhood. Pediatr Clin North Am 1995:42:1051-70.

10 Pepmueller PH, Moore TL. Juvenile spondyloarthropathies. Curr Opin Rheumatol 2000;12:269-73.

11 Prieur AM. Spondyloarthropathies in childhood. Bailliere's Clin Rheumatol 1998;12:287-307.

12 Rosenberg AM, Petty R, Oen KG, Schroeder ML. Rheumatic disease in Western Canadian Indian children. J Rheumatol 1982:9:589-92.

13 Oen K, Postl B, Chalmers IM, Ling N, Schroeder ML, Baragar FD, et al. Rheumatic disease in an Invit population. Arthritis Rheum 1986;29:65-74

14 Boyer GS, Lanier AT, Templin DW. Prevalence rates of spondyloarthropathies, rheumatoid arthritis, and other rheumatic disorders in an Alaskan Inupiat Eskimo population. J Rheumatol 1988; 15:678-83.

15 Andersson GB. Juvenile arthritis - who gets it, where and when? A review of current data on incidence and prevalence. Clin Exp Rheumatol 1999:37:367-74

16 Malleson PN, Fung MY, Rosenberg AM. The incidence of pediatric rheumatic diseases: results from the Canadian Pediatric Rheumatology Disease Registry. J Rheumatol 1996:23:1981-7.

17 Symmons DP, Jones M, Osborne J, Sills J, Southwood TR, Woo P. Pediatric rheumatology in the United Kingdom: data from the British Paediatric Rheumatology Group National Diagnostic Register. J Rheumatol 1996;23:1975-80

18 Bowyer S, Roettcher P. Pediatric rheumatology clinic populations in the United States: results of a 3 year survey. Pediatric Rheumatology Database Research Group. J Rheumatol 1996;23:1968-74.

19 Denardo BA, Tucker LB, Miller LC, Szer IS, Schaller JG. Demography of a regional pediatric rheumatology patient population. Affiliated Children's Arthritis Centers of New England. J Rheumato 1994;21:1553-61.

20 Rosenberg AM. Analysis of a pediatric rheumatology clinic population. J Rheumatol 1990;17:827-30.

21 Rosenberg AM, Petty RE. A syndrome of seronegative enthesopathy and arthropathy in children. Arthritis Rheum 1982;25:1041-7.

22 Jacobs JC, Berdon WE, Johnston AD. HLA-B27 associated spondyloarthritis and enthesopathy in childhood: Clinical, pathologic and radiographic observations in 58 patients. J Pediatr 1982; 100:521-8.

23 Burgos-Vargas R, Clark P. Axial involvement in the seronegative enthesopathy and arthropathy syndrome and its progression to ankylosing spondylitis. J Rheumatol 1989;16:192-7.

24 Burgos-Vargas R, Vazquez-Mellado J. The early clinical recognition of juvenile-onset ankylosing spondylitis and its differentiation from juvenile rheumatoid arthritis. Arthritis Rheum 1995;38:835-44.

25 Fink CW. Proposal for the development of classification criteria for idiopathic arthritides of childhood. J Rheumatol 1995:22:1566-69.

26 Pacheco-Tena C, Alvarado de la Barrera C, Lopez-Vidal Y, Vazquez-Mellado J, Richaud-Patin Y, Amieva RI, et al. Bacterial DNA in synovial fluid cells of patients with juvenile-onset spondyloarthropathies. Rheumatology (Oxford) 2001;40:920-7.

27 Masi AT. Do sex hormones play a role in ankylosing spondylitis? Rheum Dis Clin North Am 1992;18:153-76.

28 Chikanza IC, Kuis W, Heiinen CJ. The influence of the hormonal system on pediatric rheumatic diseases. Rheum Dis Clin North Am 2000;26:911-25.

29 Hamilton ML, Gladman DD, Shore A, Laxer RM, Silverman ED. Juvenile psoriatic arthritis and HLA antigens. Ann Rheum Dis 1990;49:694-7.

30 Brown M, Wordsworth P. Genotyping HLA-B27 in spondyloarthropathies. J Rheumatol 1998;25:820-1.

31 Khan MA. Update: the twenty subtypes of HLA-B27. Curr Opin Rheumatol 2000;12:235-8

32 Maksymowych WP, Gorodezky C, Olivo A, Alaez C, Wong C, Burgos-Vargas R, ef al. HLA-DRB 1 *08 influences the development of disease in Mexican Mestizo with spondyloarthropathy. J Rheumatol 1997:24:904-7.

33 Sieper J, Braun J. Pathogenesis of spondylarthropathies. Persistent bacterial antigen, autoimmunity, or both? Arthritis Rheum 1995;38:1547-54

34 Lahesmaa R, Skurnik M, Vaara M, Leirisalo-Repo M, Nissila M Granfors K, et al. Molecular mimicry between HLA B27 and yersinia, salmonella, shigella, and klebsiella within the same region of HLA alpha 1-helix. Clin Exp Immunol 1991;86:399-404.

35 Feltkamp TEW, Khan MA, Lopez de Castro. The pathogenetic role of HLA-B27. Immunol Today 1996;17:5-7.

36 Kapasi K, Inman RD. HLA-B27 expression modulates gram-negative bacterial invasion into transfected L cells. J Immunol 1992; 148:3554-9.

37 Kapasi K, Inman RD. MEl epitope of HLA-B27 confers class I-mediated modulation of gram-negative bacterial invasion. J Immunol 1994; 153:833-40

38 Pazmany L, Rowland-Jones S, Huet S, Hill A, Sutton J, Murray R, et al. Genetic modulation of antigen presentation by HLA-B27 molecules. J Exp Med 1992;175:361-9.

39 Maki-Ikola O, Yli-Kerttula U, Saario R, Tiovanan P, Granfors K. Salmonella specific antibodies in serum and synovial fluid in patients with reactive arthritis. Br J Rheumatol 1992;31:25-9.

40 Granfors K, Jalkanen S, Lindberg AA, Maki-lkola O, von Essen R, Lahesmaa-Rantala $R$, et al. Salmonella lipopolysaccharide in synovial cells from patients with reactive arthritis. Lancet 1990;335:685-8.

41 Granfors K, Jalkanen S, Toivanen P, Koski J, Lindberg AA. Bacterial lipopolysaccharide in synovial fluid cells in Shigella triggered reactive arthritis. J Rheumatol 1992; 19:500.

42 Maki-Ikola O, Lahesmaa R, Heesemann J, Merilahti-Palo R, Saario R Toivanen A, et al. Yersinia-specific antibodies in serum and synovial fluid in patients with Yersinia triggered arthritis. Ann Rheum Dis 1994:53:535-9.

43 Braun J, Latiko S, Treharne J, Eggens U, Wu P, Distler A, et al. Chlamydia pneumoniae: a new causative agent of reactive arthritis and undifferentiated oligoarthritis. Ann Rheum Dis 1994;53:100-5.

44 Sieper J, Kingsley G, Palacios-Boix A, Pitzalis C, Threharne J, Hughes R, et al. Synovial T lymphocyte-specific immune response to Chlamydia trachomatis in Reiter's disease. Arthritis Rheum 1991:34:588-98.

45 Maki-Ikola O, Nissila M, Lehtinen K, Leirisalo-Repo M, Toivanen P, Granfors K. Antibodies to Klebsiella pneumoniae, Escherichia coli and Proteus mirabilis in the sera of patients with axial and peripheral form of ankylosing spondylitis. Br J Rheumatol 1995;34:413-17.

46 Maki-Ikola O, Nissila M, Lehtinen K, Granfors K. IgA class serum antibodies against three different Klebsiella serotypes in ankylosing spondylitis. Br J Rheumatol 1998;37:1299-302.

47 Scofield RH, Kurien B, Gross T, Warren WL, Harley JB. HLA-B27 binding of peptide from its own sequence and similar peptides from bacteria: implications for spondyloarthropathies. Lance 1995:345: 1542-4.

48 Scofield RH, Warren WL, Koelsch G, Harley JB. A hypothesis for the HLA-B27 immune dysregulation in spondyloarthropathy: contributions from enteric organisms, B27 structure, peptides bound by B27, and convergent evolution. Proc Natl Acad Sci USA 1993;90:9330-4.

49 Sieper J, Braun J, Wu P, Kingsley G. T cells are responsible for the enhanced synovial cellular immune response to triggering antigen in reactive arthritis. Clin Exp Immunol 1993;91:96-102.

50 Simon AK, Seipelt E, Wu P, Wenzel B, Braun J, Sieper J. Analysis of cytokine profiles in synovial T cell clones from chlamydial reactive arthritis patients: predominance of the Th1 subset. Clin Exp Immunol 1993:94:122-6.

51 Burgos-Vargas R, Vázquez-Mellado J. Reactive arthritides. In: Cassidy JT, Petty RE, eds. Textbook of pediatric rheumatology. 4th ed. Philadelphia: Saunders, 2000

52 Mielants H, Veys EM, Joos R, Noens L, Cuvelier C, De Vos M. HLA antigens in seronegative spondylarthropathies. Reactive arthritis and arthritis in ankylosing spondylitis: relation to gut inflammation. J Rheumatol 1987; 14:466-71

53 Mielants H, Veys EM, Joos R, Cuvelier C, De Vos M, Proot F. Late onset pauciarticular juvenile chronic arthritis: relation to gut inflammation. $J$ Rheumatol 1987; 14:495-65.

54 Mielants H, Veys EM, Joos R, Cuvelier C, De Vos M. Repeat ileocolonoscopy in reactive arthritis. J Rheumatol 1987; 14:456-8.

55 Mielants H, Veys EM, Cuvelier C, Vos M, Goemaere S, Maertens M, et al. Gut inflammation in children with late onset pauciarticular juvenile chronic arthritis and evolution to adult spondyloarthropathy - a prospective study. J Rheumatol 1993;20:1567-72.

56 Mielants H, Veys EM, Cuvelier C, De Vos M, Goemaere S, De Clercq L, et al. The evolution of spondyloarthropathies in relation to gut histology. III. Relation between gut and joint. J Rheumatol 1995;22:2279-84. 
57 Mielants H, Veys EM, Cuvelier C, De Vos M, Goemaere S, De Clercq L, et al. The evolution of spondyloarthropathies in relation to gut histology. II. Histological aspects. J Rheumatol 1995;22:2273-8

58 Barabino A, Gattorno M, Cabria M, Sormani MP, Occhi M, Villavecchia $G$, et al. $99 \mathrm{mTc}$-white cell scanning to detect gut inflammation in children with inflammatory bowel diseases or spondyloarthropathies. Clin Exp Rheumatol 1998; 16:327-34.

59 Lionetti P, Pupi A, Veltroni M, Fonda C, Cavicchi MC, Azzari C, et al. Evidence of subclinical intestinal inflammation by $99 \mathrm{~m}$ technetium leukocyte scintigraphy in patients with HLA-B27 positive juvenile onset active spondyloarthropathy. J Rheumatol 2000;27:1538-41.

60 Braun J, Bollow M, Neure L, Seipelt E, Seyrekbasan F, Herbst H, et al. Use of immunohistologic and in situ hybridization techniques in the examination of sacroiliac joint biopsy specimens from patients with ankylosing spondylitis. Arthritis Rheum 1995;38:499-505.

61 Murray KJ, Luyrink L, Grom AA, Passo MH, Emery H, Witte D, et al. Immunohistological characteristics of T cell infiltrates in different forms of childhood onset chronic arthritis. J Rheumatol 1996;23:21 16-24.

62 Murray KJ, Grom AA, Thompson SD, Lieuwen D, Passo MH, Glass DN. Contrasting cytokine profiles in the synovium of different forms of juvenile rheumatoid arthritis and juvenile spondyloarthropathy: prominence of interleukin 4 in restricted disease. J Rheumatol 1998;25:1388-98.

63 Grom AA, Murray KJ, Luyrink L, Emery H, Passo MH, Glass DN, et al. Patterns of expression of tumor necrosis factor $\alpha$, tumor necrosis factor $\beta$, and their receptors in synovia of patients with juvenile rheumatoid arthritis and juvenile spondylarthropathy. Arthritis Rheum 1996;39:1703-10.

64 Gratacos J, Collado A, Filella X, Sanmarti R, Canete J, Llena J, et al. Serum cytokines (IL-6, TNF-alpha, IL-1 beta and IFN-gamma) in ankylosing spondylitis: a close correlation between serum IL-6 and disease activity and severity. Br J Rheumatol 1994;33:927-31.

65 Cabral DA, Oen KG, Petty RE. SEA syndrome revisited: a longterm followup of children with a syndrome of seronegative enthesopathy and arthropathy. J Rheumatol 1992;19:1282-5.

66 Burgos-Vargas R, Pacheco-Tena C, Vázquez-Mellado J. The juvenile onset spondyloarthritides. Rationale for clinical evaluation. Best Pract Res Clin Rheumatol (in press).

67 Hall MA, Burgos-Vargas R, Ansell BM. Sacroiliitis in juvenile chronic arthritis: a 10-year follow-up. Clin Exp Rheumatol 1987;5(suppl):65-7.

68 Sheerin KA, Giannini EH, Brewer EJ Jr, Barron KS. HLA-B27-associated arthropathy in childhood: long-term clinical and diagnostic outcome. Arthritis Rheum 1988;31:1165-70.

69 Cabral DA, Oen KG, Petty RE. SEA syndrome revisited: a longterm followup of children with a syndrome of seronegative enthesopathy and arthropathy. J Rheumatol 1992;19:1282-5.
70 Hussein A Spectrum of post-enteric reactive arthritis in childhood. Monatsschr Kinderheilkd 1987; 135:93-8.

71 Cuttica RJ, Scheines EJ, Garay SM, Romanelli MC, Maldonado Cocco JA. Juvenile onset Reiter's syndrome. A retrospective study of 26 patients. Clin Exp Rheumatol 1992;10:285-8.

72 Taccetti G, Trapani S, Ermini M, Falcini F. Reactive arthritis triggered by Yersinia enterocolitica: a review of 18 pediatric cases. Clin Exp Rheumatol 1994;12:681-4

73 Kanakoudi-Tsakalidou F, Pardalos G, Pratsidou-Gertsi P, Kansouzidou-Kanakoudi A, Tsangaropoulou-Stinga $H$. Persistent or severe course of reactive arthritis following Salmonella enteritidis infection. A prospective study of 9 patients. Scand J Rheumatol 1998:27:431-4.

74 Flato B, Aasland A, Vinje O, Forre O. Outcome and predictive factors in juvenile rheumatoid arthritis and juvenile spondyloarthropathy. J Rheumatol 1998;25:366-75

75 Minden K, Kiessling U, Listing J, Niewerth M, Doring E, Meincke J, et al. Prognosis of patients with juvenile chronic arthritis and juvenile spondyloarthropathy. J Rheumatol 2000;27:2256-63.

76 Calin A, Elswood S. The natural history of juvenile onset ankylosing spondylitis: 24 year retrospective case control study. Br J Rheumatol 1988;27:91-3.

77 García-Morteo O, Maldonado-Cocco JA, Suárez-Almazor ME, Garay E. Ankylosing spondylitis of juvenile onset: comparison with adult onset disease. Scand J Rheumatol 1983;12:246-8.

78 Jiménez J, Mintz G. The onset, evolution and final stages of juvenile AS are different from those of adult-onset AS. In: Dick CA, Calabro JJ, eds. Ankylosing spondylitis. 1 st ed. Lancaster: MTP Press; 1987.

79 Job-Deslandre C, Menkes CJ. Treatment of juvenile spondyloarthropathies with sulfasalazine. Rev Rhum Ed Fr 1993:60:489-91.

80 Kavanaugh AF. Anti-tumor necrosis factor- $\alpha$ monoclonal antibody therapy for rheumatoid arthritis. Rheum Dis Clin North Am 1998;24:593-614.

81 MacDonald TT, Hutchings P, Choy MY, Murch S, Cooke A. Tumour necrosis factor-alpha and interferon-gamma production measured at the single cell level in normal and inflamed human intestine. Clin Exp Immunol 1990;81:301-5.

82 Murch SH, Braegger CP, Walker-Smith JA, MacDonald TT. Distribution and density of TNF immunoreactivity in chronic inflammatory bowel disease. Adv Exp Med Biol 1995;371B:1327-30.

83 Present DH, Rutgeerts $P$, Targan S, Hanauer SB, Mayer L, van Hogezand RA, et al. Infliximab for the treatment of fistulas in patients with Crohn's disease. N Engl J Med 1999;340:1398-405.

84 Reiff A, Henrickson M. Prolonged efficacy of etanercept in refractory uvenile ankylosing spondylitis [abstract]. Arthritis Rheum 2001;44(suppl):292S. 